\section{AL-AZHAR}

Assiut Dental Journal
The Official Publication of The

Faculty of Dental medicine.

Al-Azhar Assiut Uniuersity.

AADJ, Vol. 2, No. 2, October (2019) - PP. 143:149

ISSn 2682-2822

\title{
Effect of Using Collagen Sponge Combined with Injectable Platelet Rich Fibrin in Post Extraction Socket
}

\author{
Ahmad Abdul-Motamed Ahmad Amer ${ }^{* 1}$, Ahmad Mohamad Adawy ${ }^{1}$, Atef Mohamed Hasaneen ${ }^{1}$
}

Codex : 17/1910

Aadj@azhar.edu.eg

\section{KEYWORDS}

Collagen sponge, I-PRF, socket, ridge resorption, exteraction.

1. Department of Oral and Maxillofacial Surgery, Faculty of Dental Medicine, Al-Azhar University, (Cairo, Boys), Egypt.

* Corresponding Author e-mail: ahmedamer.stu.p.9@azhar.edu.eg

\begin{abstract}
Aim: The aim of this study was to assess the effect of using collagen sponge combined with injectable platelet rich fibrin in post extraction socket. Subjects and Methods: 26 patients selected. All patients had a treatment plan for extraction of non-restorable single rooted maxillary tooth. Group A (control): Extraction socket was left for normal healing (blood clot), just patient presses on the gauze for promoting hemostasis. Group B (study): Extraction socket was filled with combination of collagen sponge and injectable platelet rich fibrin. In the present study, the following measurements were recorded: Width of alveolar ridge. Vertical measurements. Bone density. Bone volume. Results: Post-operative Study group showed a higher average width (5.28) of alveolar ridge than control group (3.41). Post-operative; study group showed a high volume (100.7) than control group (48.21). Post-operative; Study group showed a higher bone density (443.0) than control group (192.2). Post-operative; Study group showed a higher bone density GV (633.0) than control group (275.2).Conclusion: The use of collagen sponge with autologous I-PRF in the present study, significantly minimized ridge resorption in all dimensions.
\end{abstract}

\section{INTRODUCTION}

Socket preservation has been a source of interest for scientists and surgeons in recent times. The main principle has been to encourage socket filling, minimizing ridge resorption, and ultimately reducing or eliminating the need for further ridge augmentation ${ }^{(1)}$. It has been proposed various ridge preservation techniques following tooth extractions, including: packing of grafting materials into the socket (as autogenous graft, allograft or xenograft), using membrane in most of the cases, doing primary closure of the socket by raising a mucoperiosteal flap, sometimes immobilizing the block bone graft with screws is done $^{(2)}$.

In a clinical study, collagen sponge and xenogeneic bone were applied in dental sockets after extraction for ridge preservation. 
The results indicated that in the ridge preservation using collagen sponge and xenograft, xenograft prevents the horizontal resorption of the alveolar ridge, and the upper collagen sponge blocks the infiltration of soft tissues to the lower area, and thus it has the advantage of the enhancement of bone fill ${ }^{(3)}$.

In another study, the use of collagen matrix seal and collagen spongy, when combined with freezedried bone allograft was evaluated. Conclusions from this study were, collagen matrix seal and collagen spongy, when combined with freeze-dried bone allograft, significantly minimized ridge resorption in all dimensions ${ }^{(4)}$. Platelet-rich fibrin was a simple and strong enhancer for tissue regeneration and thus could be efficiently used in clinical medicine and dentistry. Platelet-rich fibrin is a bioscaffold and reservoir of growth factors for tissue regeneration ${ }^{(5)}$.

Injectable platelet rich fibrin is a way to accelerate and enhance the body's natural wound healing mechanisms. Platelets primarily are involved in wound healing through clot formation and the release of growth factors that initiate and support wound healing ${ }^{(6)}$. Injectable platelet rich fibrin contains and releases (through degranulation) at least seven different growth factors (cytokines) that stimulate bone and soft tissue healing ${ }^{(7,8)}$. It provides a matrix for migration of tissue-forming cells like fibroblasts and endothelial cells, which are involved in angiogenesis and are responsible for re-modeling of a new tissue ${ }^{(9)}$. Growth factors are protein produced by cells that act as signaling molecules on an appropriate cell to carry out a desired function. These proteins activate the cellular communications network and influence functions, such as cell proliferation, matrix deposition, and differentiation of tissues ${ }^{(10)}$. Therefore, the current study was an attempt to use absorbable collagen sponge mixed with injectable platelet rich fibrin in socket after tooth extraction which could be value in promotion of healing process and alveolar ridge preservation.

\section{SUBJECTS AND METHODS}

The current study was conducted on 26 patients selected from the outpatient clinic, Department of Oral and Maxillofacial surgery, Faculty of Dental Medicine, Al Azhar University, Cairo, Boys. Seventeen male patients and nine female patients participated in this study. The age ranged from 17-40 years. All patients had a treatment plan for extraction of non-restorable single rooted maxillary tooth.

Inclusion criteria: Adult patients were selected according to the following criteria; Patients with a single rooted maxillary tooth that had a treatment plan of extraction as; endodontic complication, root fracture, or trauma. Intact buccal plate of bone at the extraction site. Exclusion criteria: Patients having debilitating uncontrolled systemic diseases. Presence of acute infection. Heavy smokers. Protocol was approved by the Local Ethical Committee of Al-Azhar University (OMS2018). A total sample of at least 13 subject for each group appeared to be sufficient. The patients were divided randomly according to filling material into two groups: Group A (control): Comprised thirteen patients 9 males and 4 females. The mean age of the patients in the control group was 31.7 years. Extraction socket was left for normal healing (blood clot), just patient presses on the gauze for promoting hemostasis. Group B (study): Included thirteen patients 8 males and 5 females, and the mean age of the study group was 32.2 years. Extraction socket was filled with combination of collagen sponge and injectable platelet rich fibrin. In the present study, the following measurements were recorded: Width of alveolar ridge. Vertical measurements. Bone density. Bone volume. 


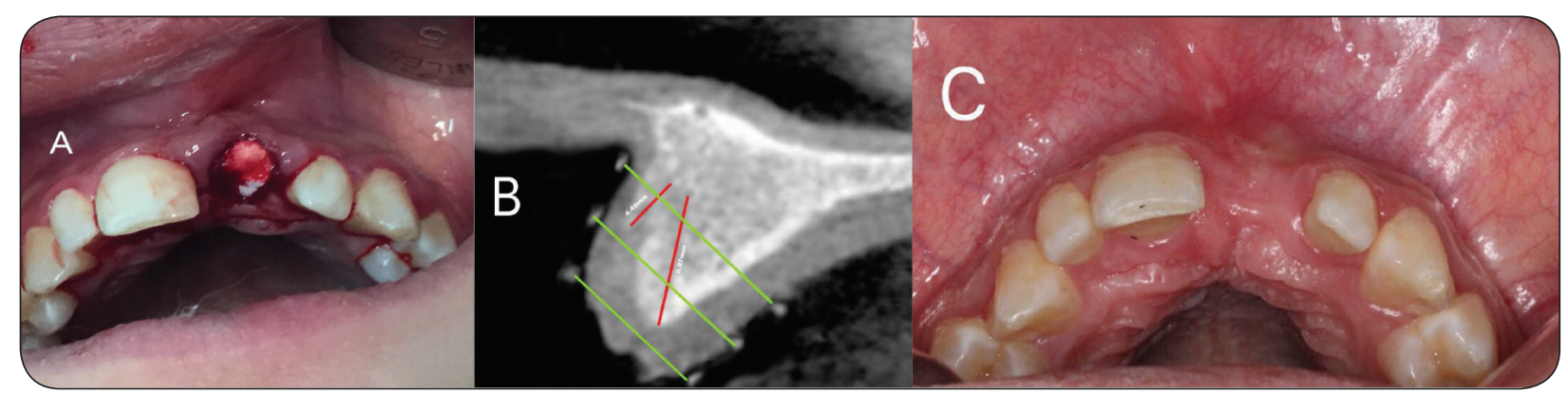

Fig. (1). a, collagen sponge b, vertical measurements, c, 6 months after ridge preservation

\section{RESULTS}

Pre-operative at mesial, Distal and Middle surface; there was a non-statistically significant difference between width of alveolar ridge measurements in the two groups. Post-operative at mesial, Distal and Middle surface; there was a statistically significant difference between width of alveolar ridge measurements in the two groups. Study group showed a higher average width (5.28) of alveolar ridge than control group (3.41). Pre-operative and Post-operative at all surface; there was a non-statistically significant difference between vertical measurements in the two groups. Pre-operative and Post-operative at all surface; there was a non-statistically significant difference between Mesiodistal dimensions in the two groups. Post-operative; there was a statistically significant difference between volume in the two groups. A study group showed a high volume (100.7) than control group (48.21). Post-operative; there was a statistically significant difference between bone density (HU) measurements in the two groups. Study group showed a higher bone density (443.0) than control group (192.2). Post-operative; there was a statistically significant difference between bone density measurements in the two groups. Study group showed a higher bone density GV (633.0) than control group (275.2).

Table (1) Comparison between the two studied groups according to width of alveolar ridge and vertical measurements and Mesiodistal dimension and volume and to bone density.

\begin{tabular}{|c|c|c|c|c|c|c|}
\hline & \multicolumn{2}{|c|}{ Control } & \multicolumn{2}{|c|}{ Study } & \multirow{2}{*}{$\mathbf{t}$} & \multirow{2}{*}{$\mathbf{P}$} \\
\hline & Mean & \pm SD & Mean & \pm SD & & \\
\hline \multicolumn{7}{|l|}{ Width } \\
\hline Pre-operative Average & 6.19 & 0.64 & 7.15 & 0.90 & $2.731^{*}$ & $0.014^{*}$ \\
\hline Post-operative Average & 3.41 & 0.74 & 5.28 & 1.01 & $4.693^{*}$ & $<0.001^{*}$ \\
\hline \multicolumn{7}{|l|}{ Vertical } \\
\hline Pre-operative Average & 9.81 & 2.76 & 8.89 & 1.67 & 0.904 & 0.378 \\
\hline Post-operative Average & 4.65 & 2.65 & 5.37 & 2.06 & 0.681 & 0.505 \\
\hline \multicolumn{7}{|l|}{ Mesiodistal } \\
\hline Pre-operative Average & 4.01 & 0.62 & 3.94 & 0.74 & 0.230 & 0.821 \\
\hline Post-operative Average & 2.99 & 0.40 & 3.25 & 0.60 & 1.132 & 0.272 \\
\hline \multicolumn{7}{|l|}{ Volume } \\
\hline$\%$ change & 79.18 & 14.81 & 61.83 & 16.26 & 24 & 0.052 \\
\hline \multicolumn{7}{|l|}{ Bone Density (HU) } \\
\hline Pre-operative & 501.8 & 113.0 & 509.8 & 95.7 & 0.178 & 0.862 \\
\hline Post-operative & 192.2 & 82.9 & 443.0 & 133.9 & $5.001^{*}$ & $<0.001^{*}$ \\
\hline \multicolumn{7}{|l|}{ Bone Density ( GV ) } \\
\hline Pre-operative & 716.8 & 162.0 & 728.8 & 137.7 & 0.179 & 0.860 \\
\hline Post-operative & 275.2 & 118.9 & 633.0 & 191.9 & $5.011^{*}$ & $<0.001^{*}$ \\
\hline
\end{tabular}

t: Student t-testp: $p$ value for comparing between the studied groups

*: Statistically significant at $p \leq 0.05$ 


\section{DISCUSSION}

The findings of present prospective randomized study indicate that ridge preservation using combination of collagen sponge with I-PRF with a flapless approach minimized ridge resorption in all dimensions in comparison to other findings recorded after tooth extraction without alveolar ridge preservation. Bone loss recorded at the coronal part and on the buccal aspect of the ridge are within the range of results reported in previous studies testing various alveolar ridge preservation surgical techniques and materials ${ }^{(11,12)}$. These studies and systematic reviews ${ }^{(13-16)}$, point to a significant reduction, but not complete elimination, in vertical and horizontal bone resorption compared to unassisted socket healing after alveolar ridge preservation procedures. The present findings confirm that complete preservation of the alveolar ridge dimensions after tooth extraction is unlikely to be attainable even if alveolar ridge preservation procedures are employed. However, the present study corresponded with previous studies where the loss of buccal marginal bone level was more pronounced on the buccal than on the lingual counterpart ${ }^{(17,18)}$. The hard tissue dimensional changes that reported in this study resemble changes reported in studies of tooth extraction and ridge preservation by others ${ }^{(19,20)}$. Those changes are also consistent with the results observed in a study that performed alveolar ridge preservation with a combination of freezed dried bone allograft (FDBA) and collagen matrix or an extracellular collagen matrix as barriers ${ }^{(21)}$.

In the present study a flapless approach was used, and regenerative materials were left exposed during healing because elevation and advancement of a full-thickness flap may cause postoperative bone resorption, marginal recession at the adjacent teeth, defective papillae, and loss of keratinized mucosa. The amount of bone resorption occurring after flapped or flapless tooth extraction remains controversial. Flapless surgery in dogs reduced the volumetric alterations on the buccal aspect irrespective of whether a grafting material was used ${ }^{(22)}$. In the present study preoperative at mesial, distal and middle surface; there was a non-statistically significant difference between the width of alveolar ridge measurements in the two groups. Postoperative at mesial, distal and middle surface; there was a statistically significant difference between the width of alveolar ridge measurements in the two groups. The study group showed a higher width $(73.84 \%)$ of alveolar ridge than the control group (55\%).

The present study also determines the change in density of alveolar socket/ridge from baseline to 6 months using a CBCT scan. Multislice and cone beam $\mathrm{CT}$ images are frequently used to determine mineral density of craniofacial bone structures. Yet, there is no consensus regarding the accuracy of CBCT for this type of analysis. While some studies advocate its use, others advocate that CBCT is not an adequate tool for this type of evaluation because the intensity values of CBCT are influenced by the characteristics of the system and by the scanned object ${ }^{23)}$. The density changes in radiographic techniques is based on the darkness and brightness of images, expressed with Hounsfield Unit in CT scan and with gray scale in CBCT. Gray scale has many applications in determining the origin of lesions and tissues and density changes, but gray scales are not the same in various devices. So far, CBCT manufacturers have not introduced a standard system for displaying gray scale. HU is a standard scheme for measuring $\mathrm{CT}$ values in $\mathrm{CT}$ scan. Some studies have shown a strong linear relationship between HU and gray scale. However, gray scale is different due to higher noise levels, more scattered radiation, high heel effect and beam hardening artifacts ${ }^{(23)}$. There is a close linear correlation consented to determine the conversion ratio to transform the gray density values of $\mathrm{CBCT}$ to that of CT (HU). In particular, in the present study, the conversion ratio was approximately $0.7(0.7 \mathrm{x}$ values of $\mathrm{CBCT}=$ values of $\mathrm{CT}){ }^{(24)}$. There was a statistically significant difference between the two groups; Study group showed a higher bone density (443.0) than control group (192.2). However, while analyzing the results it should be noted that at baseline, the mean values of density for Group I (Control) was attributed 
to normal healing, whereas for Group II (study) the mean density values were attributed to the socket grafting with a combination of collagen sponge with I-PRF.

In the present study, there was a statistically significant difference between volumes in the two groups. A study group showed a volume reduction (61.83) less than control group that shows volume reduction (79.18). The volumetric change of the extraction socket in the study group differ significantly with the control groups. This study provides clinical, volumetric and radiologic evidence to suggest that collagen sponge combined with injectable platelet rich fibrin might be a favorable alternative to conventional bone sed in the ridge preservation technique. The volumetric change of the extraction socket did not differ significantly between the treatment and control groups. This indicates that both types of membranes used ECM membrane was applied in the treatment group and a newly developed ECM membrane was applied in the control group were equally useful in preventing the collapse of the socket volume during a ridge preservation procedure ${ }^{(25)}$.

In agreement with our results, Zhang et al. (26), evaluated the clinical efficacy of platelet rich fibrin (PRF) in preserving the alveolar ridge following human tooth extraction. The results suggested that PRF was advantageous in human alveolar ridge preservation with ease of use and simple handling. Histological analysis of novel bone formation confirmed that PRF increased the quality of the novel bone and enhanced the rate of bone formation. Swati et al. (27), determine the clinico-radiographic efficacy of platelet-rich fibrin (PRF) and beta-tri-calcium phosphate with collagen $(\beta-\mathrm{TCP})$ in preserving extraction sockets. The use of either autologous PRF or $\beta$-TCP was effective in socket preservation. Results obtained from PRF were almost similar to $\beta$-TCP; therefore being autologous, nonimmune, cost-effective, easily procurable regenerative biomaterial, PRF proves to be an insight into the future biofuel for regeneration. Fiorelini et al. ${ }^{(28)}$, demonstrated that the regenerative potential of the recombinant BMP-2 in the collagen sponge compared to the use of the collagen sponge alone. Significantly greater augmentation was noted in the rhBMP-2 group. Histological findings showed generation of bone no different from native bone. In conclusion, the use of combination of collagen sponge with I-PRF in the present study, were effective in socket preservation and significantly minimized ridge resorption in all dimensions and was able to increase the quality of the novel bone and enhance the rate of bone formation due to the concentration of growth factors. These findings suggest that the growth factors contained in I-PRF may serve a role in promoting bone regeneration, over a prolonged period of time.

\section{REFERENCES}

1. Serino G, Biancu S, Iezzi G, Piattelli A. Ridge preservation following tooth extraction using a polylactide and polyglycolide sponge as space filler: a clinical and histological study in humans. Clin Oral Impl Res.2003; 14: $651-58$.

2. Horowitz R, Holtzclaw D, Rosen P. A Review on alveolar ridge preservation following tooth extraction. J Evid Based Dent Pract. 2012:3:149-60.

3. Kim Y, Yun P, Lee H, Ahn J, Kim S. Ridge preservation of the molar extraction socket using collagen sponge and xenogeneic bone grafts. Implant Dent. 2011;20:267-72.

4. Natto Z, Parashis A, Steffensen B, Ganguly R, Finkelman $\mathrm{M}$, Jeong Y. Efficacy of collagen matrix seal and collagen sponge on ridge preservation in combination with bone allograft: A randomized controlled clinical trial. J Clin Periodontol. 2017 ;44:649-65

5. Kang Y , Jeon S, Park J , Chung J , Choung Y, Choung H, et al. Platelet-Rich Fibrin is a Bioscaffold and Reservoir of Growth Factors for Tissue Regeneration. Tissue Eng. Part A.2011; 17: 349-59.

6. Geiger M, Li R, Friess W: collagen sponges for bone regeneration with rhBMP-2. Adv Drug Deliv Rev. 2003: 55;1613-1629.

7. Choukroun J, Diss A, Simonpieri A, Girard M, Schoeffler $\mathrm{C}$, Dohan S, et al. Platelet-rich fibrin (PRF): A secondgeneration platelet concentrate. PartV: Histologic evaluations of PRF effects on bone allograft maturation in sinus lift. Oral Surg Oral Med Oral Pathol Oral Radiol Endod 2006;101:299-303. 
8. Dar M, Hakim T, Shah A, Najar L, Yaqoob G, Lanker F. Use of autologous platelet-rich fibrin in osseous regeneration after cystic enucleation: A clinical study. J Oral Biol Craniofac Res. 2016;6:29-32.

9. Kang Y, Jeon S, Park J, Chung J, Choung Y, Choung H, et al. Platelet-rich fibrin is a bioscaffold and reservoir of growth factors for tissue regeneration. Tissue Eng Part A 2011;17:349-59.

10. Lydia N. Tissue engineering in oral and maxillofacial reconstruction. Tanta Dental J. 2015; 12 : 211-223.

11. Mardas N, Chadha V, Donos N. Alveolar ridge preservation with guided bone regeneration and a synthetic bone substitute or a bovine-derived xenograft: a randomized, controlled clinical trial. Clin. Oral Impl. Res. 2010. 21; 688-698.

12. Weng D, Stock V, Schliephake H. Are socket and ridge preservation techniques at the day of tooth extraction efficient in maintaining the tissues of the alveolar ridge? Euro J Oral Impl. 2011:4 ; 59-66.

13. CHF Ha“mmerle, Arau 'jo MG, Simion M, On Behalf of the Osteology Consensus Group 2011. Evidence-based knowledge on the biology and treatment of extraction sockets. Clin. Oral Impl. Res. 2012, 23 , 80-82

14. Vignoletti F, Matesanz P, Rodrigo D, Figuero E, Martin C, Sanz, M. Surgical protocols for ridge preservation after tooth extraction. A systematic review. Clin. Oral Impl. Res. 2012: 23; 22-38.

15. Wang R, Lang N. Ridge preservation after tooth extraction. Clin. Oral Impl. Res. 2012: 23; 147-156.

16. Willenbacher M, Al-Nawas B, Berres M, Kammerer P, Schiegnitz E. The effects of alveolar ridge preservation: A meta-analysis. Clin Implant Dent Relat Res.2015; 6 ; 1248-1268.

17. Araujo $\mathrm{M}$, Lindhe J: Dimensional ridge alterations following tooth extraction. An experimental study in the dog. J Clin Periodontol. 2005; 32: 212 -8.

18. Fickl S, Zuhr O, Wachtel H, Stappert C, Stein J, Hürzeler M: Dimensional changes of the alveolar ridge contour after different socket preservation techniques. J Clin Periodontol. 2008; 35: 906- 913.

19. Jung R, Philipp A, Annen B, Signorelli L, Thoma D, et al.
Radiographic evaluation of different techniques for ridge preservation after tooth extraction: A randomized controlled clinical trial. J Clin Periodontol. 2013; 40; 90-98.

20. Schneider D, Schmidlin P, Philipp A, Annen B, Ronay $\mathrm{V}$, et al. Labial soft tissue volume evaluation of different techniques for ridge preservation after tooth extraction: A randomized controlled clinical trial. J Clin Periodontol. 2014; 41: 612-617.

21. Parashis A, Hawley C, Stark P, Ganguly R, Hanley J, Steffensen B. Prospective clinical and radiographic study of alveolar ridge preservation combining freeze-dried bone allograft with two xenogeneic collagen matrices. J Periodontol. 2016; 87; 416-425.

22. Fickl S, Zuhr O, Wachtel H, Bolz W, Huerzeler M. Tissue alterations after tooth extraction with and without surgical trauma: A volumetric study in the beagle dog. J Clin Periodontol.2008; 35: 356-363.

23. Razi T, Niknami M, Alavi Ghazani F. Relationship between Hounsfield Unit in CT Scan and Gray Scale in CBCT. J Dent Res Dent Clin Dent Prospects. 2014 ; 8:107-10.

24. Cassetta M, Stefanelli L, Pacifici A, Pacifici L, Barbato E. How accurate is CBCT in measuring bone density? A comparative CBCT-CT in vitro study. Clin Implant Dent Relat Res. 2014 ; 16 :471-8.

25. Chang H, Kim S, Hwang JW, Kim S, Koo K, Klm T, et al. Comparative, randomized, double-blind clinical study of alveolar ridge preservation using an extracellular matrixbased dental resorbable membrane in the extraction socket. J Periodontal Implant Sci. 2017;47:165-173.

26. Zhang Y, Ruan Z, Shen M, Tan L, Huang W, Wang lei, et al. Clinical effect of platelet-rich fibrin on the preservation of the alveolar ridge following tooth extraction. Exp Ther Med. $2018 ; 15: 2277-86$.

27. Swati Das, Jhingran R, Bains V, Madan R, Srivastava R, Rizvi I. Socket preservation by beta-tri-calcium phosphate with collagen compared to platelet-rich fibrin: A clinicoradiographic study. Eur J Dent. 2016;10 :264-76.

28. Fiorellini J, Howell T, Cochran D, Malmquist J, Lilly L, et al. Randomized study evaluating recombinant human bone morphogenetic protein-2 for extraction socket augmentation. J Periodontol. $2005 ; 76: 605-13$. 


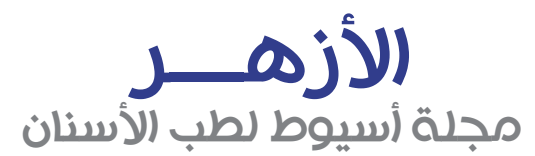

النشر الرسمي لكلية طب الأسنان

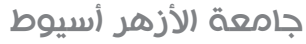

\title{
تقييم تأثير استخدام الكولاجين الاسفنجمي مع حقن الصفائح الدموية الغنية بالليفيرين بعد خلع العين الاسنان
}

\author{
احمد عبدالمعتمد احمد احمد عامر * , احمد محمد العدوى, عاطف محمد حسانين

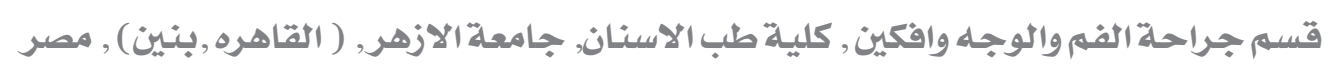 \\ AHMEDAMER.STU.P.9@AZHAR.EDU.EG البريد الالكترونى *
}

الملخص :

الهدف: كان الهدف هن هذه الدراسـة هو تقييم تأثير استخدام الكولاجين الاسفنجي هع حقن الصفائح الدموية الغنية بالليفيرين بعد خلع الاسنان.

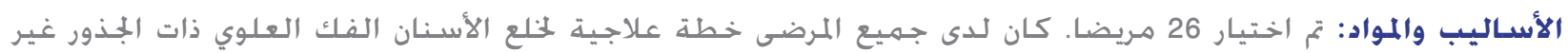

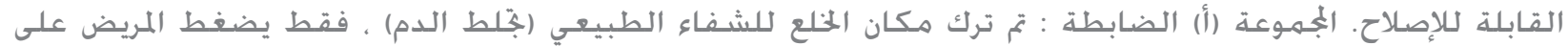

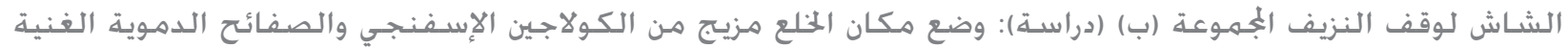

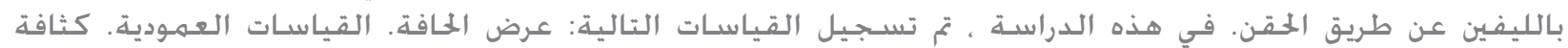

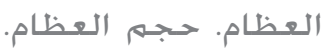

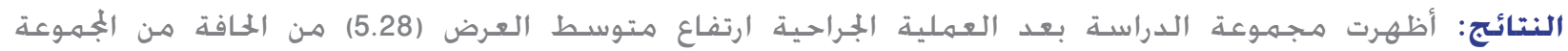

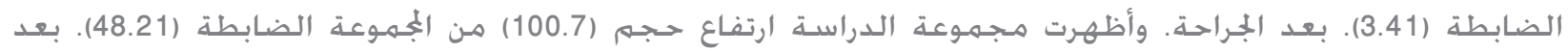

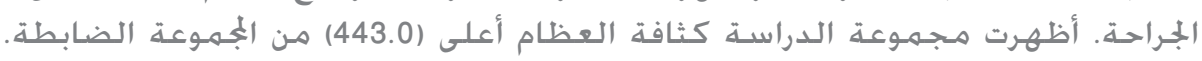

الخلاصة: إن استخدام الكولاجين الاسفنجي مع حقن الصفائح الدموية الغنية بالليفيرين ق قلل إلى حد كبير ارتشاف

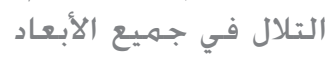

الكلمات المفتاحيه: الكولاجين الاسفنجي، حقن الصفائح الدموية الغنية بالليفيرين، جيب الفك بعد الخلع، تأكل عظام 